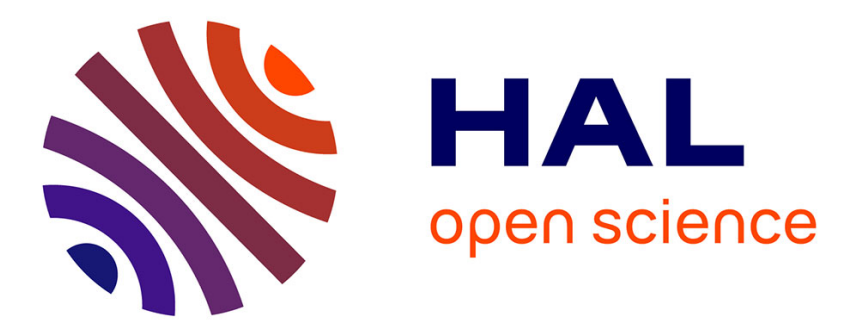

\title{
Filling a gap in the proboscidean fossil record: a new genus from the Lutetian of Senegal
}

Rodolphe Tabuce, Raphaël Sarr, Sylvain Adnet, Renaud Lebrun, Fabrice

Lihoreau, Jeremy Martin, Bernard Sambou, Mustapha Thiam, Lionel Hautier

\section{- To cite this version:}

Rodolphe Tabuce, Raphaël Sarr, Sylvain Adnet, Renaud Lebrun, Fabrice Lihoreau, et al.. Filling a gap in the proboscidean fossil record: a new genus from the Lutetian of Senegal. Journal of Paleontology, 2019, pp.1-9. 10.1017/jpa.2019.98 . hal-02408861

\section{HAL Id: hal-02408861 https://hal.science/hal-02408861}

Submitted on 8 Dec 2020

HAL is a multi-disciplinary open access archive for the deposit and dissemination of scientific research documents, whether they are published or not. The documents may come from teaching and research institutions in France or abroad, or from public or private research centers.
L'archive ouverte pluridisciplinaire HAL, est destinée au dépôt et à la diffusion de documents scientifiques de niveau recherche, publiés ou non, émanant des établissements d'enseignement et de recherche français ou étrangers, des laboratoires publics ou privés. 


\section{Filling a gap in the proboscidean fossil record: a new genus from}

\section{2 the Lutetian of Senegal}

3

4 Rodolphe Tabuce ${ }^{1}$, Raphaël Sarr ${ }^{2}$, Sylvain Adnet ${ }^{1}$, Renaud Lebrun ${ }^{1}$, Fabrice Lihoreau ${ }^{1}$, Jeremy

5 E. Martin ${ }^{2}$, Bernard Sambou ${ }^{3}$, Mustapha Thiam ${ }^{3}$, and Lionel Hautier ${ }^{1}$

6

7

${ }^{1}$ Institut des Sciences de l'Evolution, UMR5554, CNRS, IRD, EPHE, Université de

Montpellier, Montpellier, France <rodolphe.tabuce@umontpellier.fr $>$

<sylvain.adnet@umontpellier.fr><renaud.lebrun@umontpellier.fr>

<fabrice.lihoreau@umontpellier.fr ><lionel.hautier@umontpellier.fr >

${ }^{2}$ Univ. Lyon, ENS de Lyon, Université Claude Bernard Lyon 1, CNRS, UMR 5276

Laboratoire de Géologie de Lyon: Terre, Planètes, Environnement, F-69342 46 Allée d'Italie,

Lyon, France <jeremy.martin@ens-lyon.fr>

${ }^{3}$ Département de Géologie, Faculté des Sciences et Techniques, Université Cheikh Anta Diop de Dakar, B. P. 5005 Dakar, Sénégal <mbundor52@yahoo.fr $><$ bradsam@live.fr $><$ fatgeosciences@gmail.com>

Running Header: A mid-Eocene proboscidean from Senegal

Abstract.- A long hiatus encompassing most of the Eocene (end of the Ypresian to the early Priabonian) breaks up the proboscidean evolutionary history, which is otherwise documented by a rich fossil record. Only two post Ypresian localities from West Africa (Mali and Senegal) yielded scarce Moeritherium-like dental remains. Here, we study one of these remains from Senegal and name a new genus, Saloumia. This taxon, confidently mid-Lutetian in age, evokes Moeritherium and elephantifoms in view of its wrinkled enamel, the lack of centrocrista, and 
its strong lingual cingulum. However, due to its pronounced bunodonty, which departs from the bunolophodonty of both Moeritherium and elephantifoms, we cannot exclude that Saloumia documents an early experiment in dental diversity among Paleocene-Eocene proboscideans, without direct relationships with later proboscideans.

UUID: http://www.zoobank.org/0B6B83F8-817D-498C-A672-8FFA8F81A978

\section{Introduction}

Although the Afro-Arabian landmass has played a pivotal role in the evolutionary history of early placental mammals (Werdelin and Sanders, 2010), the sub-Saharan Paleogene fossil record remains very scarce, particularly in West Africa, where relatively little paleontological work has been carried out. However, the potential to discover Eocene placentals was demonstrated over half a century ago when a fragmentary proboscidean molar was described from the middle Eocene (Lutetian) of M'Bodione Dadere, Senegal by Gorodiski and Lavocat (1953). These authors compared this molar with those of Moeritherium, a genus from the late Eocene-early Oligocene period. Interestingly, they correctly noticed that the M'Bodione Dadere proboscidean was significantly smaller than all known Moeritherium species. Despite this substantial morphological difference, Gorodiski and Lavocat (1953) were reluctant to establish a new taxon based on this fragmentary molar, judging that Paleogene proboscideans were too poorly known to substantiate the definition of a new taxon. At the time, early proboscidean evolution was documented by just four genera, only known from the late Eocene (Moeritherium and Barytherium) and early Oligocene (Moeritherium, Phiomia and Palaeomastodon) of the Fayum, Egypt (e.g., Andrews, 1906; Osborn, 1936). After more than fifty years of field research, the fossil record of stem proboscideans is now much better known 
(Gheerbrant and Tassy, 2009; Sanders et al., 2010). Considerable progress has been made in several other parts of Africa (Morocco, Algeria, Libya, Kenya, and Ethiopia) and the Arabian Peninsula (Oman and Saudi Arabia), notably at the late Paleocene-early Eocene transition (Gheerbrant et al., 1998a, 2005, 2012; Gheerbrant, 2009) and, to a lesser degree, at the late Eocene-early Oligocene transition (Delmer et al., 2006; Delmer, 2009; Adnet et al., 2010; Seiffert et al., 2012; Jaeger et al., 2012; Pickford 2015; Al-Kindi et al., 2017).

Despite these fundamental advances, some unresolved problems persist. Among them, the origin and phylogenetic position of the genus Moeritherium remain uncertain. Two phylogenetic scenarios have been recently proposed for the relationships of Moeritherium within Proboscidea. First, according to Seiffert et al. (2012), Moeritherium could have a basal position in the phylogeny, near Daouitherium and Numidotherium, two stem proboscideans from the Ypresian of Morocco and Algeria, respectively. Second, Moeritherium has a more elevated position in the phylogeny, being considered as the sister-group of the clade Deinotheriidae-Elephantiformes (Seiffert, 2007; Delmer, 2009; Gheerbrant and Tassy, 2009; Ferretti and Debruyne, 2011; Cooper et al., 2014). In any case, these contradictory scenarios illuminate longstanding uncertainties regarding the transition from early proboscideans to elephantiforms (palaeomastodonts and elephantoids). Particularly, the homology between the lower incisors of early proboscideans and the ever-growing lower tusks of elephantiforms is still debated (Delmer, 2009; Jaeger et al., 2012; Al-Kindi et al., 2017).

Current data suggest that the transition from early proboscideans to elephantiforms occurred during the end of the Eocene (Priabonian) (Fig. 1a), but a simple examination of the Paleogene proboscidean fossil record reveals geographical and temporal sampling biases in our understanding of the evolutionary history of proboscideans. Earliest proboscideans are only documented from Moroccan deposits, while other Paleogene species are known from few African (e.g., Algeria, Egypt, Libya, Ethiopia, and Kenya) and Arabian sites (Saudi Arabia and 
Oman). Most importantly, this history is largely truncated by a hiatus encompassing the end of the Ypresian to the early Priabonian, so that the proboscidean fossil record is virtually unknown during most of the Eocene (Sanders et al., 2010) (Fig. 1a). It is noteworthy that the group is absent from the rich faunas from Gour Lazib (late early or early middle Eocene, Algeria), Chambi (late early or early middle Eocene, Tunisia) and Namibia (?Lutetian-Bartonian) (e.g., Adaci et al., 2016; Pickford et al., 2008). Proboscideans are also absent from the only two unambiguous middle Eocene continental mammalian sites in Africa, i.e. the faunas of Aznag in Morocco (Tabuce et al., 2005) and Mahenge in Tanzania (Kaiser et al., 2006). In contrast, the only two ?mid-Eocene localities that yielded proboscidean remains were from West Africa. Arambourg et al. (1951) described Moeritherium sp. from two isolated molars discovered from marine sediments near In Tafidet, Mali (middle or late Eocene) (see Gheerbrant et al., 1998a fig.6c; Delmer et al., 2006; O’Leary et al., 2006). Also from middle Eocene marine sediments, Gorodiski and Lavocat (1953) described ?Moeritherium sp. based on the Senegalese molar here studied. Since its initial description, this molar has never been figured; Domning (1986), Gheerbrant et al. (1998a), and Delmer et al. (2006) briefly discussed its morphology and concluded that it was too small to belong to a Moeritherium species.

In order to better document this peculiar Eocene proboscidean, we organized systematic prospecting for fossil vertebrates at and around M'Bodione Dadere in 2010 and 2011. Although we discovered a rich marine fauna represented by numerous sharks and rays, no additional mammalian specimens have been discovered to the exception of an indeterminable minute mammalian tooth fragment. Considering the difficulties to discover new specimens of proboscideans in the rare Eocene Senegalese outcrops, we reassess the Moeritherium-like molar from M'Bodione Dadere. Both its provenance (West Africa) and age (Lutetian) make this tooth a pivotal asset to better understand the early history of proboscideans, as it fills an important gap in their paleogeographic and chronological fossil record. 


\section{Geological setting}

M'Bodione Dadere village is located north of the town of Kaolack in Sine-Saloum region, central-western part of Senegal (Fig. 2). In this flat area, outcrops are absent due to an important coverage of Quaternary to Recent sands (10-20 meters), which uncomformably overly Paleogene to Pliocene levels. Access to a detailed stratigraphy and to Paleogene deposits is only possible thanks to drill cores and water-well cuttings. Fortuitously, sediments excavated from levels attributed to two Lutetian-Bartonian shallow marine formations yielded vertebrate fossils.

From the water-well of Tiavandou, South to Kaolack (Fig. 2), nummulitic limestone attributed to the Taïba Formation (late Lutetian to early Bartonian) (Roger et al., 2009a; Sarr, 2013) yielded several teeth, 18 vertebrae, and rib fragments of an archeocete identified as 'Zeuglodon' cf. osiris by C. Arambourg (Elouard, 1966). More recently, in a revision of the African fossil record of archeocetes, Gingerich (2010) suggested that these remains were too large to be attributed to Saghacetus osiris (the new name for Zeuglodon osiris), its size being more similar to Dorudon atrox, another archeocete well known from the early Priabonian of the Fayum. Unfortunately, after unfruitful research in the collections of the University of Dakar, the specimens seem to have been lost.

In the northern of the Sine-Saloum region, other water-well cuttings attributed to the middle Eocene Lam Lam Formation yielded vertebrate remains. The most recent example is the discovery of an actinopterygian maxilla attributed to an amiid (O'Leary et al., 2012) in Tewrou Poram, North to the town of Gossas (Fig. 2). The earliest discovery of vertebrates in the Lam Lam Formation corresponds to that of the M'Bodione Dadere proboscidean. On the 24th of August 1952, Alexandre Gorodiski was in charge of geological mapping in the area of 
Thiès (on behalf of the Federal Direction of Mines and Geology of French West Africa) when he discovered the proboscidean molar from cuttings of the 20 meters deep well of M'Bodione Dadere; the molar was described by R. Lavocat (Gorodiski and Lavocat, 1953; see also Lavocat, 1955). By chance, A. Gorodiski also collected samples of the coquina limestone from the well cuttings. This revealed two new fragments of mammal teeth showing 'condylarth' affinities (Gevin et al., 1975; Sudre, 1979); these indeterminable specimens, housed in the collections of the University of Montpellier, also evoke herodotiine macroscelideans by size and gross morphology (RT, pers. obs.).

In order to reconstruct the geological context of the M'Bodione Dadere proboscidean, we compared the stratigraphic sequence established by Gorodiski and Lavocat (1953) with nearby logs from drill cores (Gossas, Ngolothie, and Kaolack; Fig. 2) and with our direct observations of recent water-well cuttings located at Sanghaye Bele village $(11 \mathrm{~km}$ southeast of M'Bodione Dadere) (Fig. 2). At M'Bodione Dadere and Sanghaye Bele, the fossiliferous deposits attributed to the Lam Lam Formation correspond to those of a coquina limestone and a yellow to white clayey limestone alternating with marls; at M'Bodione Dadere these deposits are capped by phosphate nodules. The invertebrate fauna is composed of echinoids and molluscs, among them the lamellibranch Ostrea meunieri which is known from the 'Lutetian' of Senegal (Tessier, 1952; see Roger et al., 2009b p.16). Well samples from M'Bodione Dadere and Sanghaye Bele did not provide any characteristic microfauna, but equivalent levels from the Ngolothie borehole near Kaolack (Fig. 2) yielded the planktonic foraminifera Globigerinatheka gr. index, Cassigerinelloita amekiensis, and Pseudohastigerina micra, which characterize E8 to E11 biozones (middle Lutetian to early Bartonian) (Sarr, 2013). North of the Senegalese basin, the base of the Lam-Lam Formation (Pallo limestone and phosphate clays) is E8 in age (middle Lutetian) (presence of Hantkenina aragonensis) (Flicoteaux, 1975; Roger et al., 2009a), whereas the top of the formation (Lam-Lam marls) yielded a rich planktonic 
151 foraminifera association (Truncorotaloides rohri, T. topilensis, Globigerapsis sp., G. index,

152 Globorotalia collactea, G. bolivariana, G. pentacamerata, and Hantkenina spp.), which 153 indicates E9 biozone (middle Lutetian) (Flicoteaux, 1974; Roger et al., 2009b). These regional 154 correlations indicate a secure middle Lutetian age (E8-E9 biozones, $44 \mathrm{Ma}$, Vandenberghe et 155 al., 2012) for the M'Bodione Dadere proboscidean.

\section{Material and methods}

Repositories and institutional abbreviations.- the holotype MNHN.F.MCA 1 and unique specimen of Saloumia gorodiskii is housed in the collections of the Museum National d'Histoire Naturelle, Paris (MNHN). A CT scan of MNHN.F.MCA 1 was acquired at the Montpellier Rio Imaging (MRI) micro-CT imaging station Skyscan 1076 (Montpellier, France). Image segmentation and 3D rendering were performed using manual segmentation with Avizo 7.1 (VSG). A 3D reconstruction of MNHN.F.MCA 1 was deposited in MorphoMuseum Department of Palaeontology, London, UK).

\section{Systematic paleontology}


177 Type species._Saloumia gorodiskii n. gen. n. sp., only species.

179 Diagnosis.—As for the type species, by monotypy.

Etymology.-From the coastal river Saloum which flows south of the village of M'Bodione Dadere.

Remarks. - The specimen described here is identified as a proboscidean based on its relative

large size, quadrituberculy, wrinkled enamel, small parastyle, well-developed lingual cingulum, blunt paraconule mesiolabially located to the protocone, and the lack of a centrocrista. The particular combination of these dental characters is unknown is other African "ungulates" from the Paleogene (hyraxes, embrithopods, sirenians, and "condylarths").

Holotype.-MNHN.F.MCA 1, right upper molar, which rests on indurated coquina limestone.

Diagnosis.-Saloumia gorodiskii differs from Eritherium and Phosphatherium by larger size, wrinkled enamel, strong lingual cingulum, and no centrocrista; its morphology also differs from Phosphatherium by a pronounced bunodonty. Saloumia gorodiskii differs from Moeritherium ssp., Phiomia and Palaeomastodon by smaller size, more bunodont and not bunolophodont positions. 
Occurrence.-M'Bodione Dadere $\left(14^{\circ} 20.706^{\prime} \mathrm{N}, 16^{\circ} 11.151^{\prime} \mathrm{W}\right)$, Lam-Lam Formation, middle

Lutetian, planktonic foraminiferal biozones E8-E9, 44 Ma.

Description.-MNHN.F.MCA 1 is a low-crowned and incompletely preserved upper molar, missing its distal part $(\mathrm{L}>10.7 \mathrm{~mm} ; \mathrm{W}=12.3 \mathrm{~mm})$ (Figs. 3-4). The apexes of the four principal cusps (paracone, metacone, protocone, and hypocone) were broken away (“scalped"), possibly before fossilization; there are no significant wear on these cusps. Only the mesial flanks of the metacone and hypocone are preserved. The hypocone is relatively centrally positioned and as large as the protocone and was certainly wider than the metacone. The paracone and protocone are fully bunodont and connected at their base but without a high loph connecting them. However, this loph, if it was incipiently developed, may have been erased as the apexes of protocone and paracone were broken away. A large paraconule, whose apex is also broken away, is underlined by dental wear facets; it is closely appressed to the mesiolabial flank of the protocone; the paraconule also connects to the mesial cingulum. There is no trace of a metaconule. The shallow valley between the paracone and metacone is deeper and larger than that between the protocone and hypocone. The transverse valley is thus poorly defined. The cingulum is continuous from the labial border of the paracone to the lingual face of the teeth; it enamel is wrinkled, especially on the paracone and lingually to the protocone. fossiliferous locality and the holotype. 
Remarks. - The thick enamel, the lack of a well-defined ectoflexus, and the parastyle, which is not enlarged and not mesially projected but strongly appressed to the paracone, precludes that MNHN.F.MCA 1 is a deciduous premolar. Likewise, the probability that MNHN.F.MCA 1 corresponds to a fully molariform premolar is also excluded because the molarization of premolars in proboscideans is documented only during the mid-early Oligocene (in the elephantiforms Phiomia and Palaeomastodon).

\section{Systematic attribution and discussion}

Gorodiski and Lavocat (1953) attributed MNHN.F.MCA 1 to ?Moeritherium sp. in view of its quadritubercular dental pattern and the morphology of its cingulum. However, they insisted that 'it would not be prudent to exclude the possibility that this specimen may belong to another [new] primitive bunodont genus, especially because main cusps appear to have been more obviously bunodont than those of known Moeritherium species' (Gorodiski and Lavocat, 1953:316). During the 1950's, Paleogene proboscideans were only documented by Moeritherium, Barytherium, Phiomia, and Palaeomastodon. The genus Moeritherium was then considered as ancestral among proboscideans. Today, the phylogenetic position of Moeritherium remains debated. Such an uncertainty is surprising considering that dental, cranial, and postcranial anatomy of Moeritherium has been well-known for more than a century. The genus is particularly well documented in the Fayum where it is known by two species. The consensus view consists in attributing all specimens from the Gebel el Qatrani Formation (early Oligocene) to Moeritherium trigodon, and those from the Qasr el Sagha Formation (late Eocene) to M. lyonsi (Sanders et al., 2010; but see Delmer et al., 2006). 
These two Fayumian moeritheres are characterized by a bunolophodont dental pattern. The oldest attested Moeritherium species, M. chehbeurameuri, corresponds to a smaller and more lophodont taxon; it was described from the Priabonian of Bir El Ater, Algeria (Delmer et al., 2006). This species was also listed from the ?late Eocene locality of Dur At-Talah, Libya (Jaeger et al., 2010, 2012) and from the late Eocene locality of Birket Qarun-2, Fayum (Sanders, pers. comm. to RT, 2019; see also Seiffert, 2008, 2010).

Saloumia evokes all these Moeritherium species by three derived characters: wrinkled enamel, the lack of centrocrista, and the well-developed lingual cingulum that was considered as a diagnostic feature of the genus (Figs. 3-4). As a result, these three dental characters could support a sister-group relationship between Saloumia and Moeritherium. However, the association of a convolute and a distocrista (see Delmer et al., 2006) distally to the hypocone, which is also a diagnostic character of the upper molars of Moeritherium, cannot be described in Saloumia due to the poor preservation of the holotype. Saloumia also evokes the Fayumian Moeritherium species by quadrituberculy, small parastyle, blunt paraconule mesiolabially located to the protocone, and blunt crest joining the protocone to the parastyle via the paraconule. However, these traits are primitive among proboscideans and thus do not support a close relationship between Saloumia and Fayumian Moeritherium species. Moreover, Saloumia is twice smaller than Moeritherium trigodon and M. lyonsi, and also differs from these two species by a relative lower crown, a more labial position of both the protocone and hypocone, and by the occurrence of a labial cingulum. We note however that M. "gracile", which is synonym of M. lyonsi (see Sanders et al. 2010; Sanders, pers. comm. to RT, 2019) has however a labial cingulum according to Delmer et al. (2006). Finally, as mentioned by Gorodiski and Lavocat (1953), the bunodonty of Saloumia markedly differs from the bunolophodonty of all the Fayumian moeritheres. 

viewed as primitive for Proboscidea. As such, Moeritherium has long been recognized as close to the origin of the order (see also Seiffert et al., 2012). In contrast, nowadays Moeritherium is

276 often interpreted as a highly specialized genus (Court 1994), more closely related to the deinotheriid-elephantiform clade than to the older genera Phosphatherium, Daouitherium, and Numidotherium (e.g. Delmer, 2009; Gheerbrant and Tassy, 2009; Sanders et al., 2010; Ferretti and Debruyne, 2011; Cooper et al., 2014). The true lophodonty of earliest Eocene genera was then considered as the primitive dental pattern of proboscideans (Gheerbrant et al., 2005). Following this hypothesis, the bunolophodonty of the Fayumian Moeritherium would derive from a true lophodonty. This result was strengthened by the description of the Priabonian lophodont M. chehbeurameuri.

Nevertheless, in our opinion, the question of the primitive dental pattern of moeritheriids is not resolved yet (see also Seiffert et al. 2012). Indeed, Moeritherium sp. from the middle/late Eocene of In Tafidet, Mali (Arambourg et al., 1951) is clearly more bunodont than its penecontemporaneous M. chehbeurameuri (Supplemental Data). As a result, we cannot exclude that Moeritherium derives from a bunodont incipiently bilophodont lineage morphologically close to Saloumia. Interestingly, the Malian Moeritherium also shares with Saloumia a minute ectostyle on the labial cingulum. This trait is primitive when compared to M. chehbeurameuri. The species from In Tafidet appears also primitive by comparison with M. chehbeurameuri and Saloumia by the occurrence of both a postparacrista and premetacrista (Supplemental Data); these crests constitute the centrocrista when associated with the ectostyle (this style is then named mesostyle, e.g., Gheerbrant et al., 2012). Accordingly, the primitive dental morphology of Moeritherium is yet uncertain. Interestingly, a bunodont incipiently bilophodont origin for this genus recently received significant support from the discovery of Eritherium, a late Paleocene proboscidean characterized by bunodont incipiently bilophodont molars 
(Gheerbrant, 2009). Furthermore, Khamsaconus, another early Ypresian proboscidean from Morocco, displays the same bunodont incipiently bilophodont pattern. This dental pattern is today viewed as primitive for proboscideans (Gheerbrant et al., 2012).

Direct comparisons with the holotype of Khamsaconus, a very small DP4 and unique specimen, is however impossible. Note that the fragmentary bunodont-bunolophodont lower molar attributed to Khamsaconus by Gheerbrant et al. (1998b) is now attributed to a basal hyracoid (see Gheerbrant et al., 2005:286). Khamsaconus (the DP4) was never included in a phylogenetic analysis with both Eritherium and Phosphatherium, but Gheerbrant et al. (2012) favored a close phylogenetic relationship between these three genera. Saloumia only shares with Eritherium primitive features: quadrituberculy, low crown, reduced parastyle (compared with Phosphatherium), blunt crest joining the protocone to the parastyle, and labial position and larger size of the protocone and hypocone relative to the paracone and metacone respectively. Most importantly, Saloumia differs from Eritherium and Phosphatherium by four derived characters: larger size, wrinkled enamel, lack of a continuous centrocrista, and strong lingual cingulum. Saloumia further differs from Eritherium by a more pronounced bunodonty. Phosphatherium and other Eocene genera (Daouitherium, Barytherium, and Arcanotherium) clearly depart from Saloumia by their true lophodonty. Among them, the undetermined species Daouitherium sp., known by a unique lower molar (Gheerbrant et al., 2005 p.285), is however of similar size. Although larger and fully lophodont, Arcanotherium evokes Saloumia by its moderately wrinkled enamel and the development of its lingual cingulum. Such derived characters are also present in the bunolophodont Phiomia and Palaeomastodon. These basal elephantiforms also share with Saloumia the lack of centrocrista, a strong lingual cingulum, and a variable occurrence of an ectostyle. The latter character is for instance present in AMNH 13449 (Palaeomastodon beadnelli; see Osborn 1936:144) and NHMUK M8851 (Phiomia serridens; see Tassy 1982:234). Palaeomastodon and Phiomia 
differ however from Saloumia by a larger size, the lack of connection between the paraconule and the parastyle, a more lingual position of both the protocone and hypocone, and four main cusps of similar size. Finally, the tritoloph (the third loph, distal to the metaloph), which is diagnostic of Phiomia and Palaeomastodon, cannot be checked in Saloumia due to the poor preservation of the specimen.

To conclude, although poorly known, Saloumia appears sufficiently distinct from other early proboscideans to be considered a valid genus. Saloumia shares with stem early Paleogene proboscideans (Eritherium and Phosphatherium) only primitive features. Most importantly, three derived characters observed in Saloumia (wrinkled enamel, lack of centrocrista, and strong lingual cingulum) could indicate a possible affinity with either Moeritherium or basal elephantiforms. If correct, this hypothesis would push back the origin of the (Moeritherium(Elephantiformes-Deinotheriidae)) clade well into the middle Eocene and generates considerable ghost lineages within proboscidean phylogeny (Fig. 1b). However, this hypothesis remains highly speculative given our current level of knowledge on Saloumia. Its very pronounced bunodonty is well-distinct from the bunolophodonty of Moeritherium and basal elephantiforms, so that Saloumia could also document an early experiment in dental diversity among Paleocene-Eocene proboscideans, with no direct relationships with later Paleogene proboscideans.

\section{Acknowledgments}

3D data acquisition was performed using the $\mu \mathrm{CT}$ facilities of the MRI platform member of the national infrastructure France-BioImaging supported by the French National Research Agency (ANR-10-INBS-04, «Investments for the future»), and of the Labex CEMEB (ANR-10-LABX0004) and NUMEV (ANR-10-LABX-0020). This research is part of the PaleoSen project 
(www.paleosen.com), and was supported by the French ANR-PALASIAFRICA Program (ANR-08-JCJC-0017), PICS-CNRS, the International Exchange Scheme of the Royal Society, and the National Geographic Society's Global Exploration Fund (Northern Europe).

\section{Accessibility of supplemental data}

Data available from the Dryad Digital Repository: https://doi.org/10.5061/dryad.51c59zw4c

\section{References}

Adaci, M., Bensalah, M., Tabuce, R., Mebrouk, F., Marivaux, L., Otero, O., Zaoui, D., Benyoucef, M., and Mahboubi, M., 2016, L'Eocène continental du complexe de Gour Lazib (Sahara nord-occidental, Algérie): Mémoire du Service Géologique de l'Algérie, v. 19, p. $63-89$.

Adnet, S., Cappetta, H., and Tabuce, R., 2010, A new Eocene vertebrate fauna (selachians and mammals) from southwestern Morocco: preliminary report. Age and palaeobiogeographical implications: Geological Magazine, v. 147, p. 860-870.

Al-Kindi, M., Pickford, M., Al-Sinani, Y., Al-Ismaili, I., Hartman, A., and Heward, A., 2017, Large mammals from the Rupelian of Oman - Recent finds: Fossil Imprint, v. 73, p. $300-321$.

Andrews, C.W., 1906, A descriptive catalogue of the Tertiary Vertebrata of the Fayûm, Egypt, London, $324 \mathrm{p}$.

Arambourg, C., Kikoine, J., and Lavocat, R., 1951, Découverte du genre Moeritherium Andrews dans le tertiaire continental du Soudan: Comptes Rendus de l'Académie des Sciences, Paris, v. 233, p. 68-70. 
Cooper, L.N., Seiffert, E.R., Clementz, M., Madar, S.I., Bajpai, S., Hussain, S.T., and Thewissen, J.G.M., 2014, Anthracobunids from the Middle Eocene of India and Pakistan are stem perissodactyls: PLoS ONE, v. 9, p. e109232.

Court, N. 1994, The periotic of Moeritherium (Mammalia, Proboscidea): homology or homoplasy in the ear region of Tethytheria McKenna, 1975?: Zoological Journal of the Linnean Society, v. 112, p. 13-28.

Delmer, C., 2005, Les premières phases de différenciation des proboscidiens (Tethytheria, Mammalia): le rôle de Barytherium grave de Libye: Thèse du Muséum national d'histoire naturelle, Paris, $413 \mathrm{p}$.

Delmer, C., 2009, New data on the Paleogene proboscidean Numidotherium savagei: reassessment of its generic attribution and interpretations of the homologies of the lower incisors in the proboscideans: Acta Palaeontologica Polonica, v. 54, p. 561-580.

Delmer, C., Mahboubi, M., Tabuce, R., and Tassy, P., 2006, A new species of Moeritherium (Proboscidea, Mammalia) from the Eocene of Algeria: new perspectives on the ancestral morphotype of the genus: Palaeontology, v. 49, p. 421-434.

Domning, D.P., Ray, C.E., and McKenna, M.C., 1986, Two new Oligocene desmostylians and a discussion of tethytherian systematics: Smithsonian Contributions to Paleobiology, v. 59 , p. $1-56$.

Elouard, P., 1966, Découverte d'un archéocète dans les environs de Kaolack: Notes Africaines, v. 109 , p. $8-10$.

Ferretti, M. P., and R. Debruyne., 2011, Anatomy and phylogenetic value of the mandibular and coronoid canals and their associated foramina in proboscideans (Mammalia): Zoological Journal of the Linnean Society, v. 161, p. 391-413. 
Flicoteaux, R., 1974, Biozonation des formations paléogènes de la retombée orientale du dôme de Ndias (Sénégal occidental), Vth African Colloquium on Micropalaeontology, AddisAbeba, Ethiopia, 1972: Madrid, Enadimsa, p. 349-362.

Flicoteaux, R., 1975, Sur l'attribution à 1'Eocène moyen des couches calcaires et argilophosphatées de Pallo (Plateau de Thiès, Sénégal occidental): Bulletin de la Société Géologique de France, v. 17, p. 430-434.

Gevin, P., Mongereau, N., and Truc, G., 1975, La Hammada du Dra (Sahara Algerien, Frontière Algero-Marocaine). Etat des connaissances actuelles: Documents du Laboratoire de Géologie, Faculté des Sciences, Lyon, p. 305-319.

Gheerbrant, E., 2009, Paleocene emergence of elephant relatives and the rapid radiation of African ungulates: Proceedings of the National Academy of Sciences USA, v. 106, p. 10717-10721.

Gheerbrant, E., Bouya, B., and Amaghzaz, M., 2012, Dental and cranial anatomy of Eritherium azzouzorum from the Paleocene of Morocco, earliest known proboscidean mammal: Palaeontographica Abt. A, v. 297, p. 151-183.

Gheerbrant, E., Sudre, J., Cappetta, H., and Bignot, G., 1998a, Phosphatherium escuilliei du Thanétien du Bassin des Ouled Abdoun (Maroc), plus ancien proboscidien (Mammalia) d'Afrique: Géobios, v. 30, p. 247-269.

Gheerbrant, E., Sudre, J., Tassy, P., Amaghzaz, M., Bouya, B., and Iarochene, M., 2005, Nouvelles données sur Phosphatherium escuilliei de l'Eocène inférieur du Maroc, apports à la phylogénie des Proboscidea et des ongulés lophodontes: Géodiversitas, v. 27, p. 239-333.

Gheerbrant, E., Sudre J., Sen S., Abrial C., Marandat B., Sigé B., and Vianey-liaud M.. 1998b, Nouvelles données sur les mammifères du Thanétien et de l'Yprésien du Bassin 

202.

422

Gheerbrant, E., and Tassy, P., 2009, L'origine et l'évolution des éléphants: Comptes Rendus Palevol, v. 8, p. 281-294.

Gingerich, P.D., 2010, Cetacea, in Werdelin, L., and Sanders, W. J., eds., Cenozoic mammals of Africa: Berkeley, University of California Press.

Gorodiski, A., and Lavocat, R., 1953, Première découverte de mammifères dans le tertiaire continental (Lutétien) du Sénégal: Comptes Rendus Sommaires de la Société Géologique de France, v. 15, p. 314-316.

Illiger, C.D., 1811, Prodromus systematis mammalium et avium additis terminis zoograaphicis utriusque classis, Salfeld, C., 302 p.

Jaeger, J.-J., Salem, M.J., Abolhassan Bilal, A., Benammi, M., Chaimanee, Y., Duringer, P., Marandat, B., Marivaux, L., Métais, E., Schuster, M., Valentin, X., Viriot, L., Hammuda, O., and Brunet, M., 2012, Dur at Talah vertebrate locality revisited: new data on its stratigraphy, age, sedimentology and mammalian fossils, in Salem, M. J., Elbakai, M. T., and Abuturruma, Y., eds., Geology of Southern Libya, Volume 1: Malta, Gutenberg Press, p. 241-258.

Kaiser, T.M., Ansorge, J., Arratia, G., Bullwinkel, V., Gunnell, G.F., Herendeen, P.S., Jacobs, B., Mingram, J., Msuya, C., and Musolff, A., 2006, The maar lake of Mahenge (Tanzania); unique evidence of Eocene terrestrial environments in sub-Sahara Africa: Zeitschrift der Deutschen Gesellschaft für Geowissenschaften, v. 157, p. 411-431.

Lavocat, R., 1955, Titres et travaux scientifiques, Romorantin, Imprimerie Centrale, 95 p.

Linnaeus, C., 1758, Systema naturae per regna tria naturae, secundum classes, ordines, genera, species cum characteribus, differentiis, synonymis, locis. Vol. 1: Regnum animale. Editio decima, reformata., Stockholm, Sweden, Laurentii Salvii, 824 p. 
O’Leary, M.A., Roberts, E.R., Bouare, M., Sissoko, F., and Tapanila, L., 2006, Malian Paenungulata (Mammalia: Placentalia): new African afrotheres from the early Eocene: Journal of Vertebrate Paleontology, v. 26, p. 981-988.

O’Leary, M.A., Sarr, R., Malou, R., Sow, E.H., Lepre, C., and Hill, R.V., 2012, A new fossil amiid from the Eocene of Senegal and the persistence of extinct marine amiids after the Cretaceous-Paleogene boundary: Copeia, v. 4, p. 603-608.

Osborn, H.F., 1936, Proboscidea. A monograph of the discovery, evolution, migration and distinction of the mastodonts and elephants of the world: vol 1. Moeritherioidea, Deinotherioidea, Mastodontoidea, American Museum Press, 802 p.

Pickford, M., 2015, Large ungulates from the basal Oligocene of Oman: 2- Proboscidea: Spanish Journal of Palaeontology, v. 30 (2), p. 209-222.

Pickford, M., Senut, B., Morales, J., Mein, P., and Sanchez, I.M., 2008, Mammalia from the Lutetian of Namibia: Memoir of the Geological Survey of Namibia, v. 20, p. 465-514.

Roger, J., Banton, O., Barusseau, J.P., Castaigne, P., Comte, J.-C., Duvail, C., Nehlig, P., Noël, B.J., Serrano, O., and Travi, Y., 2009a, Notice explicative de la cartographie multicouches à 1/50 000 et 1/20 000 de la zone d'activité du Cap-Vert. Ministère des Mines, de l'Industrie et des PME, Direction des Mines et de la Géologie, Dakar, p. 120.

Roger, J., Barusseau, J.P., Duvail, C., Nehlig, P., Noël, B.J., and Serrano, O., 2009b, Notice explicative des cartes géologiques à 1/500 000 du bassin sédimentaire sénégalais. Ministère des Mines, de l'Industrie et des PME, Direction des Mines et de la Géologie, Dakar, p. 48.

Sanders, W.J., Gheerbrant, E., Harris, J.M., Saegusa, H., and Delmer, C., 2010, Proboscidea, in Werdelin, L., and Sanders, W. J., eds., Cenozoic Mammals of Africa: Berkeley, University of California Press, p. 161-251. 
Sarr, R., 2013, Ostracodes nouveaux du Paléogène du Sine-Saloum (Sénégal, Afrique de l'Ouest) : biostratigraphie, paléoenvironnement: Revue de Paléobiologie, v. 32, p. 569588.

Seiffert, E.R., 2007, A new estimate of afrotherian phylogeny based on simultaneous analysis of genomic, morphological, and fossil evidence: BMC Evolutionary Biology, v. 7, no. 224, p. 1-13.

Seiffert, E.R., 2010, Chronology of Paleogene mammal localities, in Werdelin, L., and Sanders, W. J., eds., Cenozoic Mammals of Africa: Berkeley, University of California Press, p. $19-26$.

Seiffert, E.R., Bown, T.M., Clyde, W.C., and Simons, E.L., 2008, Geology, paleoenvironment, and age of Birket Qarun Locality 2 (BQ-2), Fayum Depression, Egypt, in Fleagle, J. G., and Gilbert, C. C., eds., Elwyn Simons: a search for origins, Springer, p. 71-86.

Seiffert, E.R., Nasir, S., Al-Harthy, A., Groenke, J.R., Kraatz, B.P., Stevens, N.J., and AlSayigh, A.R., 2012, Diversity in the later Paleogene proboscidean radiation: a small barytheriid from the Oligocene of Dhofar Governorate, Sultanate of Oman: Naturwissenschaften, v. 99, p. 133-141.

Sudre, J., 1979, Nouveaux mammifères éocènes du Sahara Occidental: Palaeovertebrata, v. 9, no. 3 , p. $83-115$.

Tabuce, R., Adnet, S., Cappetta, H., Noubhani, A., and Quillevéré, F., 2005, Aznag (bassin d'Ouarzazate, Maroc), nouvelle localité à sélaciens et mammifères de l'Eocène d'Afrique: Bulletin de la Société Géologique de France, v. 176, p. 381-400.

Tassy, P., 1982, Les principales dichotomies dans l'histoire des Proboscidea (Mammalia) ; une approche phylogénétique: Geobios, v. 6, p. 225-245. 
Tessier, F., 1952, Contribution à la stratigraphie et à la paléontologie de la partie ouest du Sénégal (Crétacé et Tertiaire): Bulletin de la Direction des Mines de l'Afrique Occidentale Française, Dakar, v. 14, p. 570.

Vandenberghe, N., Hilgen, F.J., and Speijer, R.P., 2012, The Paleogene Period, in Gradstein, F. M., Ogg, J. G., Schmitz, M. D., and Ogg, G. M., eds., The Geological Time Scale 2012: Oxford, Elsevier Science, p. 855-921.

Werdelin, L., and Sanders, W.J., 2010, Cenozoic Mammals of Africa, University of California Press, 986 p.

\section{Figure captions}

Figure 1: Phylogeny of Paleogene proboscideans based on the cladistics analysis proposed by Delmer (2009), Gheerbrant and Tassy (2009), Gheerbrant (2012), and Seiffert et al. (2012); grey zone shows the important gap in their fossil record. The question mark indicates that Omanitherium could be closer to Arcanotherium and Numidotherium than to Barytherium as proposed by Pickford (2015) and Al Kindi et al. (2017) (1); possible phylogenetic relationships of Saloumia gorodiskii n. gen. n. sp. from the mid-Lutetian of Senegal (2). Following this scenario, Saloumia could represent a suprageneric taxa close to the clade including Moeritherium and Elephantiformes.

Figure 2: Geographic position, stratigraphic position, and regional correlations of M'Bodione Dadere site that yielded the holotype of Saloumia gorodiskii n. gen. n. sp. 
516 Figure 3: Saloumia gorodiskii n. gen. n. sp., MNHN.F.MCA 1, right upper molar, in occlusal 517 (stereo pair) (1), oblique mesial (2), and oblique lingual (3) views.

518

519 Figure 4: Saloumia gorodiskii n. gen. n. sp., MNHN.F.MCA 1, right upper molar, in occlusal 520 view (3D rendering from X-ray microtomography).

521 


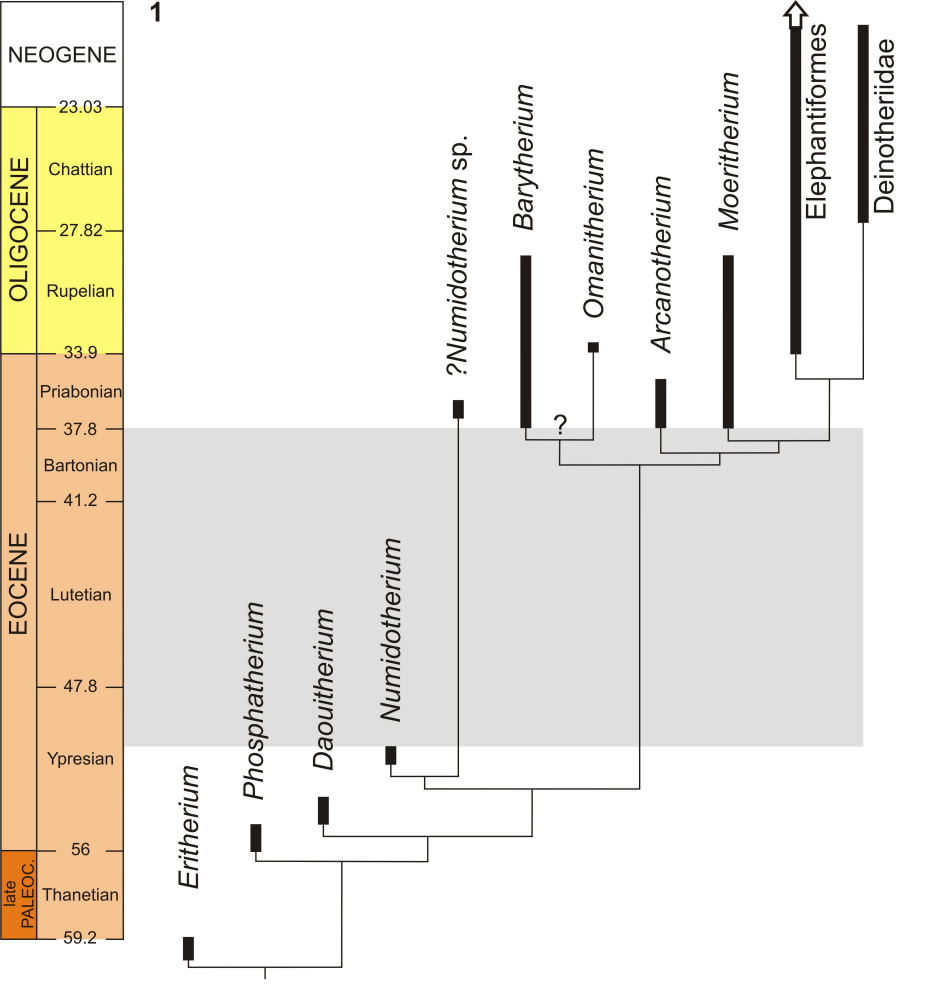


1 - MBODIONE DADERE $\quad 2$ - SANGHAYE BELE

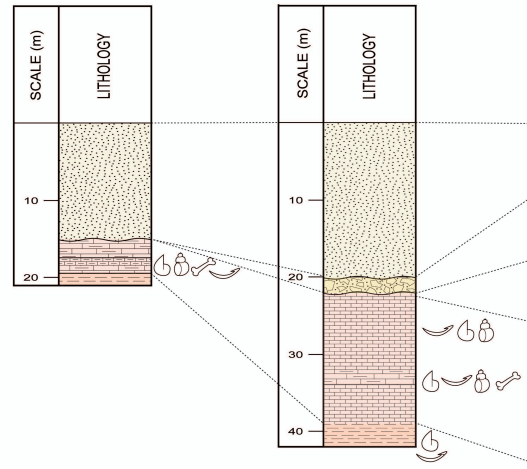

$-15^{\circ} 00^{\prime \prime} \mathrm{N}$

- TAIBA NDIAYE

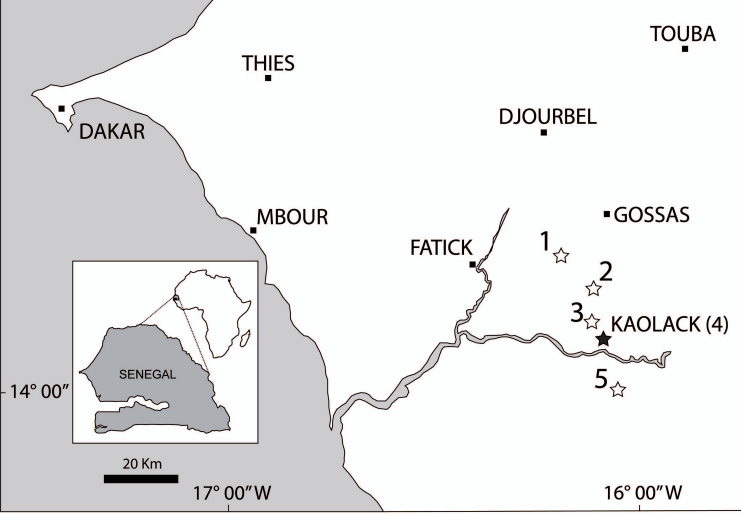

3 - NGOLOTHIE

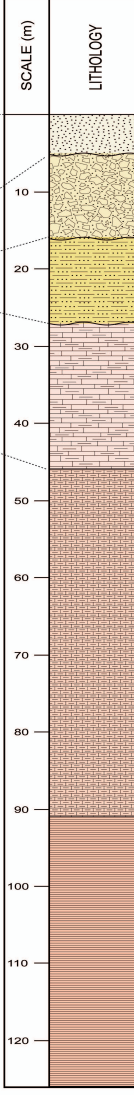

4 - KAOLACK
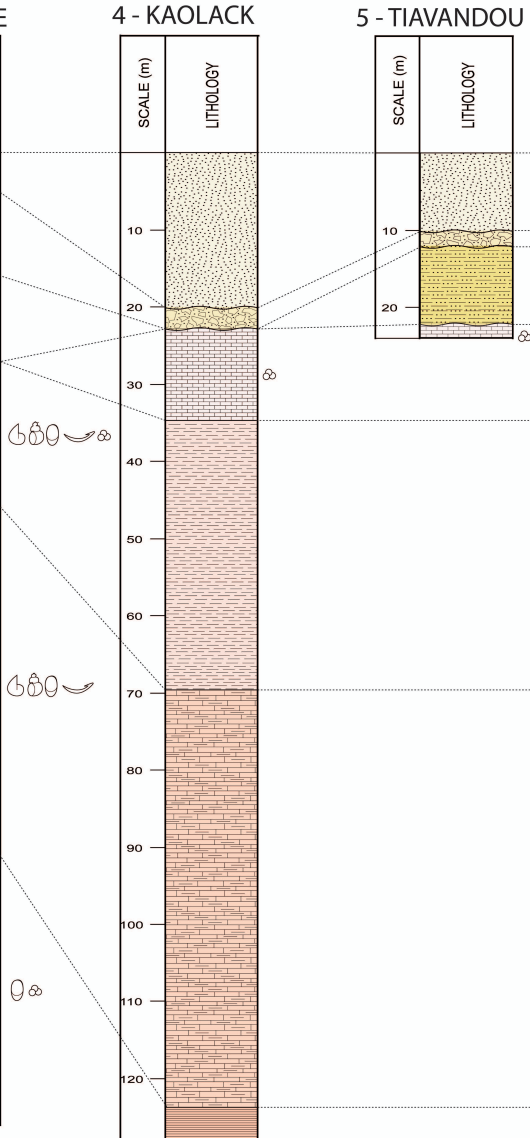

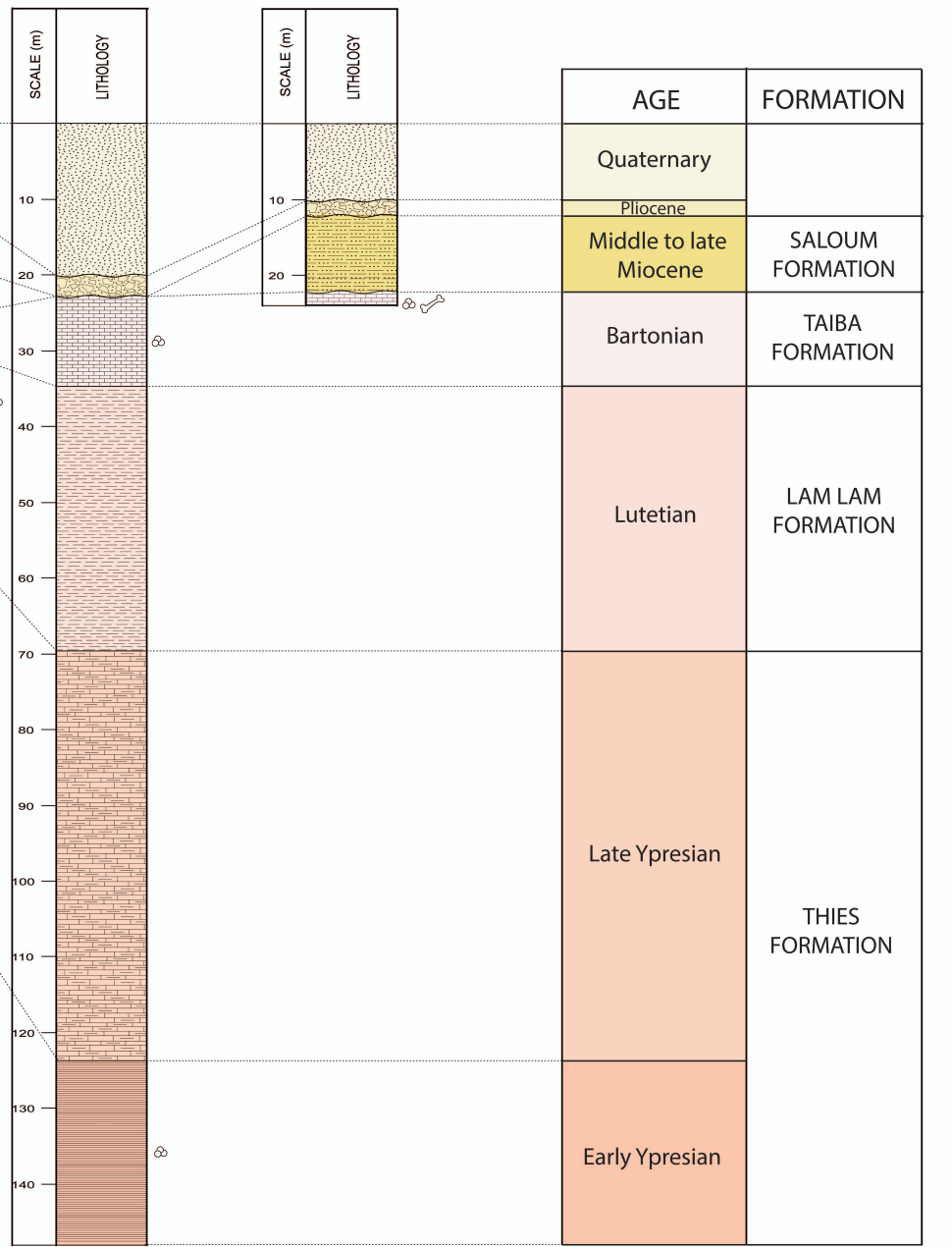



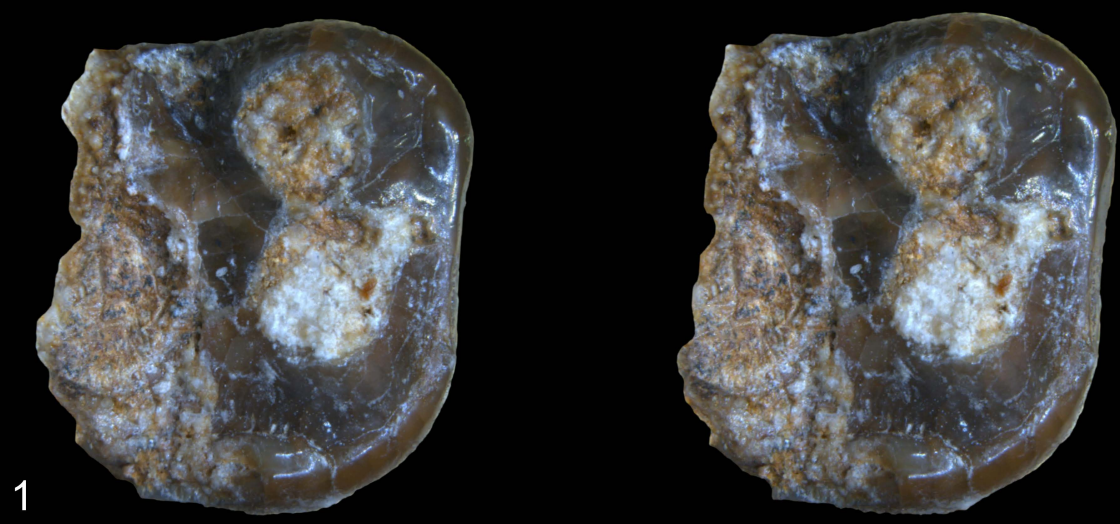

\section{$4 \mathrm{~mm}$}
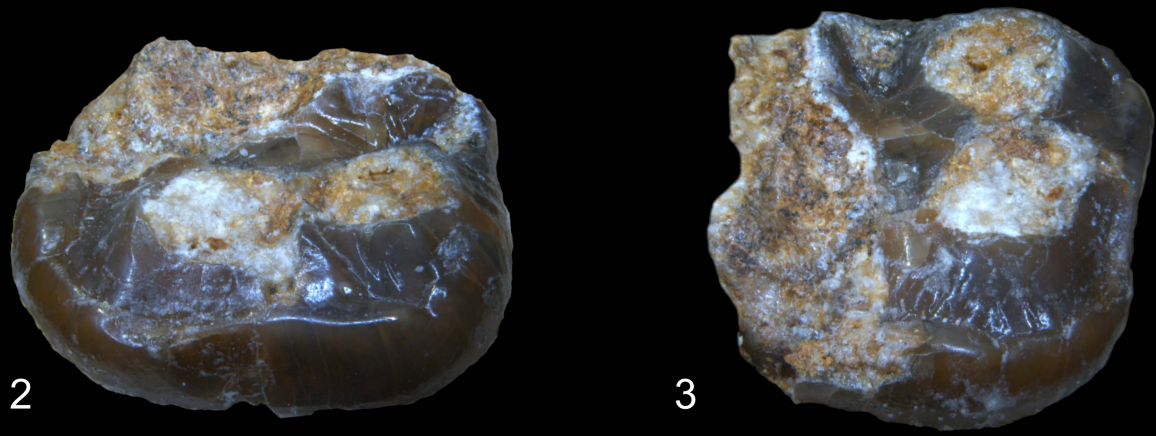
mesial flank of

ectostyle the metacone

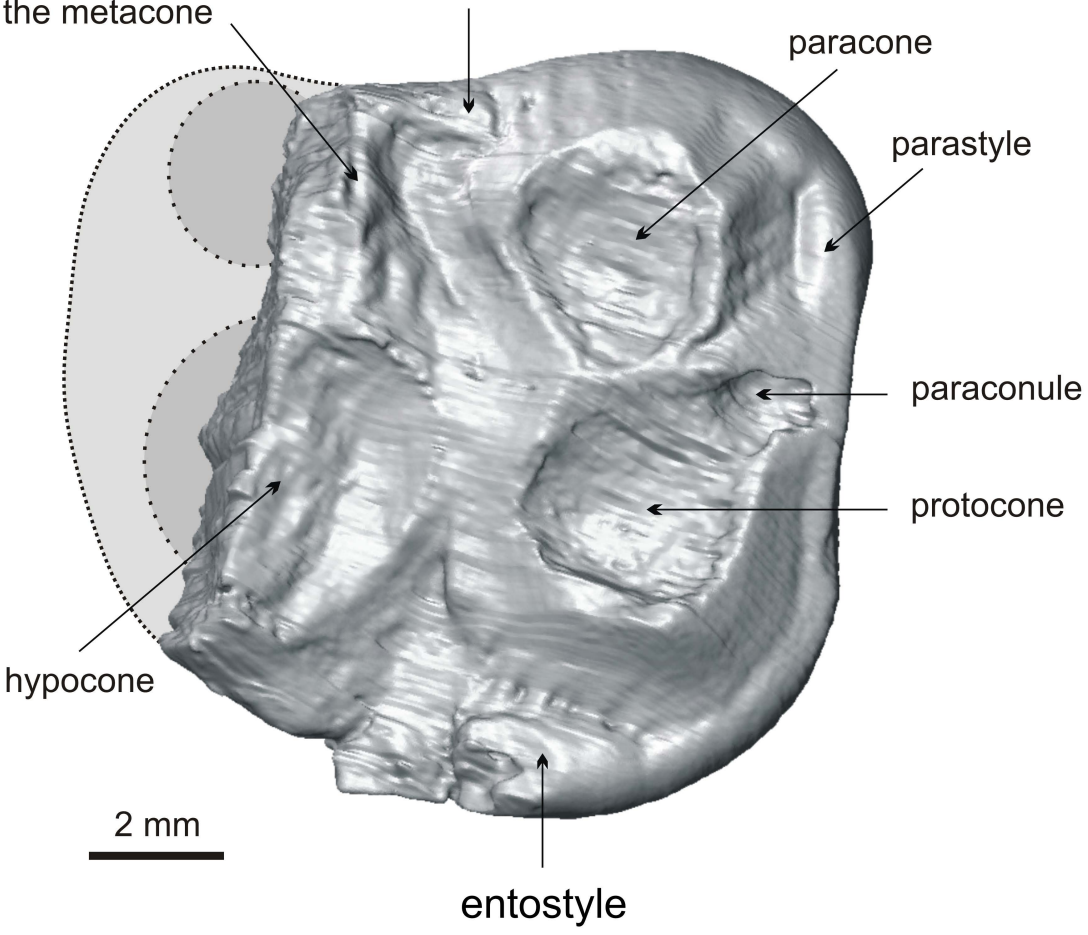

